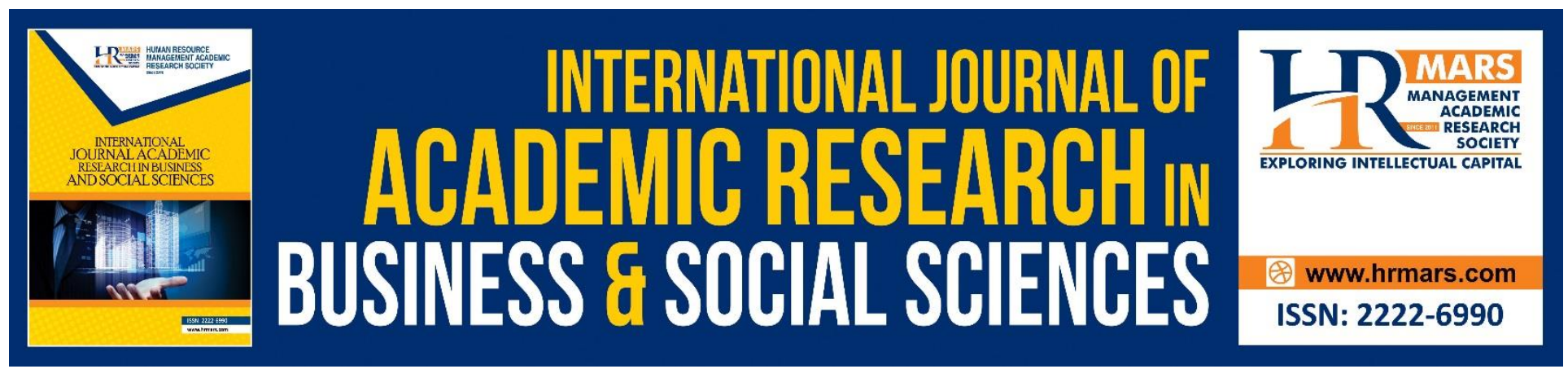

\title{
Analysis of the Siri Nurani Paintings through Elements of Symmetry in Ethnomathematic Contexts
}

\section{Rushana Sulaiman @ Abd Rahim, Mat Redhuan Samsudin, Halim Husain}

To Link this Article: http://dx.doi.org/10.6007/IJARBSS/v10-i9/8067

DOI:10.6007/IJARBSS/v10-i9/8067

Received: 07 July 2020, Revised: 29 July 2020, Accepted: 15 August 2020

Published Online: 08 September 2020

In-Text Citation: (Abd Rahim, Samsudin, \& Husain, 2020)

To Cite this Article: Abd Rahim, R. S@., Samsudin, M. R., \& Husain, H. (2020). Analysis of the Siri Nurani Paintings through Elements of Symmetry in Ethnomathematic Contexts. International Journal of Academic Research in Business and Social Sciences. 10(9), 1152-1165.

\section{Copyright: (c) 2020 The Author(s)}

Published by Human Resource Management Academic Research Society (www.hrmars.com)

This article is published under the Creative Commons Attribution (CC BY 4.0) license. Anyone may reproduce, distribute, translate and create derivative works of this article (for both commercial and non-commercial purposes), subject to full attribution to the original publication and authors. The full terms of this license may be seen

at: http://creativecommons.org/licences/by/4.0/legalcode

Vol. 10, No. 9, 2020, Pg. 1152 - 1165

Full Terms \& Conditions of access and use can be found at http://hrmars.com/index.php/pages/detail/publication-ethics 


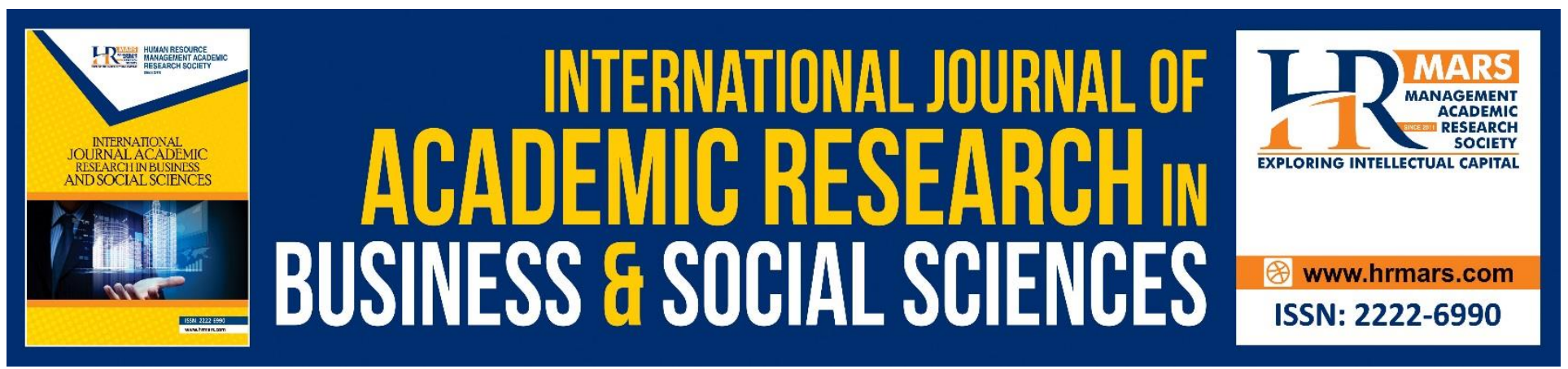

\title{
Analysis of the Siri Nurani Paintings through Elements of Symmetry in Ethnomathematic Contexts
}

\author{
Rushana Sulaiman @ Abd Rahim \\ Faculty of Art \& Design, MARA University of Technology, Malaysia \\ Email: rushana@uitm.edu.my \\ Mat Redhuan Samsudin \\ Faculty of Art and Design, MARA University of Technology, Malaysia \\ Email: redhuansamsudin@uitm.edu.my \\ Halim Husain \\ Postgraduate Studies, ASWARA, Malaysia \\ Email: abdulhalim@aswara.edu.my
}

\begin{abstract}
This research aims to provide theoretically clear information in the paintings discipline of art appreciation for traditional Malay-based artworks through Ethnomathematic thought. The main focus of the study is to review the factors that support the relationship between aspects of formalistic art for describing the concept of symmetry that exists through the beauty of design patterns in the paintings featuring traditional Malay images. This research involves analytical study of paintings through qualitative approach with the implementation of descriptive inter-disciplinary. The symmetry properties are examined meticulously in order to classify the paintings via transformations which involve four basic repetitions via such as translation, rotation, reflection and glide reflection. This process will build a structure known as symmetry group frieze. Frieze pattern is a pattern in two dimensional surfaces that repeat in one direction. Written and visual data information is collected through documentation, visual recording and observation methods to gain information regarding the subject, design and meaning of the art works studied.The findings of the study show that the artworks of Siri Nurani incorporating elements of traditional Malay buildings featuring design symmetry. The concept framework mapping used in the investigation underpins the subject design and aesthetic meaning to classify the design of the paintings using the symmetry transformation process. Implications of the research shows that the paintings not only can be viewed from the formalistic artistic point of view, but can be seen through the Ethnomathematic contexts via the application of characteristics of symmetry in the production of the artworks.
\end{abstract}

Keywords: Art Appreciation, Ethnomathematic, Frieze Pattern, Siri Nurani, Symmetry. 
INTERNATIONAL JOURNAL OF ACADEMIC RESEARCH IN BUSINESS AND SOCIAL SCIENCES Vol. 10, No. 9, 2020, E-ISSN: 2222-6990 @ 2020 HRMARS

\section{Introduction}

Ethnomathematics manifestations in Malay culture have inspire shape and meaning through the application of ideas in mathematical thinking. It has been proved in the history of the Malay community where we can see the use of traditional mathematical in artworks by using Malay ornaments. The term of Ethnomathematics is derived when cultures and mathematics are studied in an integrated manner by several western researchers. Ethnomathematics is defined as mathematics that is built along with the value system, culture and society's view where mathematics is taught and developed (Ismail, 2004).

The relationship between mathematics and culture can be seen from various aspects, namely arts, educations, literatures and economies. According to Shinley (2001) there are two approaches that are closely related to Ethnomathematics which are communications and networkings. Communication carries the meaning of explanation in thinking and the exchange of ideas more too cultural diversity in analysing and calculating mathematical strategies. Communication is more closely related to Ethnomathematics which means finding a relationship between mathematics with other subjects. It includes religion, art, weaving, music or festivals that make mathematics a part of daily learning and experience.

The application of mathematical skills have long existed among the art artists, so many geometric forms are used as reference to produce a combination of motifs and patterns which are beautiful and symmetry. In Malay heritage, some Etnomathematic manifestations affect the Malay society in terms of thought and its cultural history (Anuwar, 2013). Salleh (2009) states that an object is said to have symmetrical properties if each section of the object, which is a result of the distribution of the point, line or plane as the centre or axis of the object, consists of similar parts. Symmetry is a transformation that allows objects or patterns to remain unchanged by maintaining the original shape and size of motifs during the reversal process. The base of repetition for producing symmetric patterns is through translation, reflection, rotation and a sliding reflection (Basaree, 2008).

The mathematical concept in the paintings can be seen through the implied meanings via fine composition and patterns. The produce of art work requires skills, creativity, thinking and knowledge in relation to the nature of life.Paintings of Siri Nurani highlighted the Malay-Islamic cultural style that applied geometrical motifs. This art work is presented symmetrically by repetitive methods in accordance with the Malay-Islamic aesthetic principles that give a clear and implied meaning to the concept of Awan Larat (Basaree, 2016). The combination of several geometric motifs is not only forming an identity of an art work, but also shows the creativity of the artist.

\section{Previous Studies}

Mostly previous research examined the underlying factors of art appreciation that can influence the subject, shapes and meanings in traditional Malay such as songket, wood carvings, handicrafts and pottery. This research is conducted to identify the concept of symmetry through formalistic analysis of art in the paintings of Siri Nurani. The purpose is to classify symmetry in the design of motif patterns. This makes better research. 
INTERNATIONAL JOURNAL OF ACADEMIC RESEARCH IN BUSINESS AND SOCIAL SCIENCES Vol. 10, No. 9, 2020, E-ISSN: 2222-6990 @ 2020 HRMARS

Although there are a lot of research about mathematics and arts that have been conducted but not in paintings where none have been studied extensively, whether through books, journals, articles or theses. Past research had only relied on mathematical thinking in the art of crafts including writing and journal article by Ruzaika Omar Basaree which discusses the relationship between the principles of cosmology and geometry in wood carving. While Aziz (2016) wrote about mathematical concepts and practices in songket weaving.

\section{The Purpose of the Study}

This research contributes new information's to the existing knowledge in the field of art. It can be viewed from various philosophies of knowledge's and explored using various methods, namely the elements of art seen through mathematical concepts. A thorough understanding towards the basis of the mapping of the conceptual framework derived from the appreciation of art and the concept of symmetry is an underlying pattern design in the Malay tradisional paintings studied. The combinations of these concepts are adapted to form a conceptual framework that is thought to be in line with the analysis in this research.

\section{Theoretical Framework}

This research is based on a combination of interdisciplinary approaches using concepts in Ethnomathematics as grand theory and referred to as extra aesthetics. Intra aesthetic explanations, on the other hand, involve the concept of art appreciation (formalistic) and the concept of symmetrical transformation to see the sub-group design of the seven basic frieze patterns analysed in the work of Siri Nurani. The framework of this study is used as a reference that can reveal the questions in the study. Through this combination, the concepts involved can be adapted within the framework of this study.

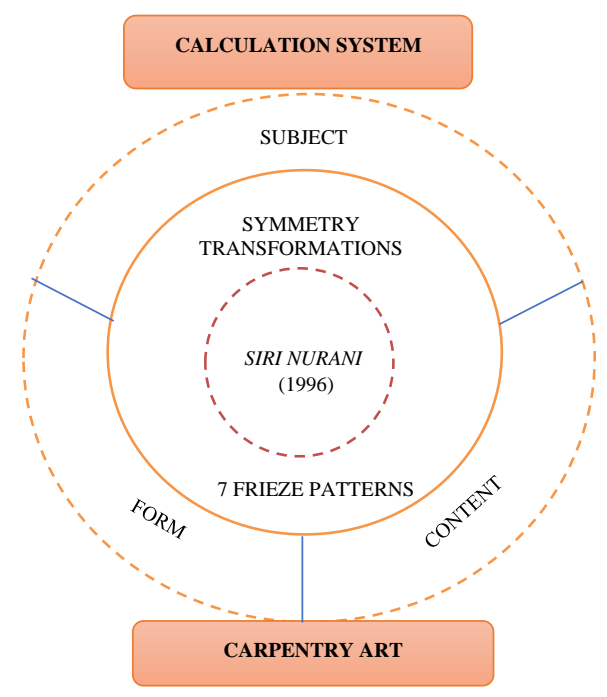

Figure 1.Theoretical framework is adapted from the concept of artistic appreciation, formalistic, symmetric transformation, frieze patterns and Ethnomatematical patterns 
INTERNATIONAL JOURNAL OF ACADEMIC RESEARCH IN BUSINESS AND SOCIAL SCIENCES Vol. 10, No. 9, 2020, E-ISSN: 2222-6990 @ 2020 HRMARS

\section{Research Methodology}

A descriptive qualitative approach to using the design of a composition analysis case on symmetric elements, it is focused on shapes, patterns and motifs in the art carving of catan artworks. There are three data collection methods that are used such as observation, visual recording and documentation analysis. Data is collected based on empirical data that is obtained while in the field.

\section{Analysis of the Siri Nurani Artwork}

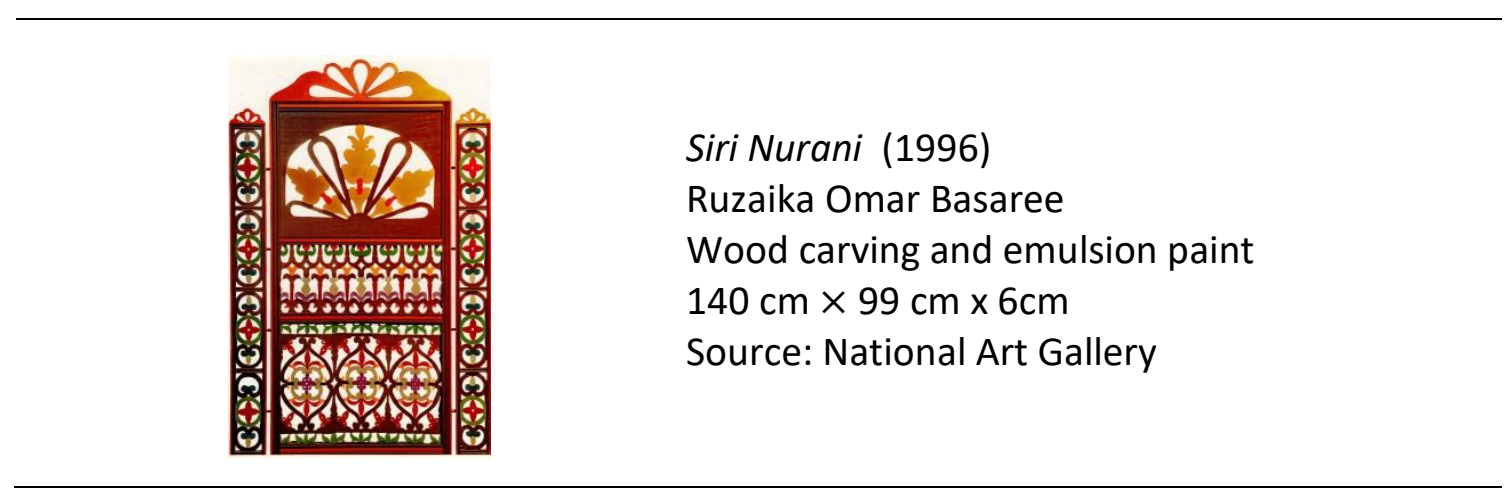

Figure 2. Siri Nurani Paintings (1996)

Siri Nurani paintings is a square-framed creation that shows the concept of using wood carving as a basis. The variety of motif carvings with techniques shows sequential and continuous arrangement resulting in a combination of interesting patterns. The artistic of the Siri Nurani produced in 1996 is a construction that is formed like a wooden gate. Its head is made of semi-circular plywood perforated with petal shape. Siri Nurani paintings show geometric shaped motifs, which is a sketch featuring a circle-shaped line pattern, Bunga Pecah Empat or A triangle shape (Ahmad \& Idris, 1996). On the Figure 2 above, the symmetry is also seen as the underlying works by displaying a line of axis in the midst of vertical, horizontal, semi-circle and circle of the motifs. These motifs were categorized to be identified and analyzed through Siri Nurani artwork which is:

Table 1. Geometric design and symmetry of motifs by Siri Nurani art work

\begin{tabular}{c|c|}
\hline \multicolumn{3}{c}{ Pattern design of Siri Nurani art work (1981) } \\
\hline & Circle Motifs \\
\cline { 2 - 3 } & Vertical Reflection \\
\hline
\end{tabular}

Siri Nurani paintings display the Tangen Circle Motifs as a pattern design that displays a consecutive circle combination. These motifs have a black point in the circle, which forms a chain that is connected 
INTERNATIONAL JOURNAL OF ACADEMIC RESEARCH IN BUSINESS AND SOCIAL SCIENCES Vol. 10, No. 9, 2020, E-ISSN: 2222-6990 @ 2020 HRMARS

in one line (Jusoh et al., 2011). In terms of its size, the motifs are fixed and have no significant difference showing the thread of parallel and continuous motifs. Table 1 also describes the symmetry concepts of image recurrence process through a vertical reflection. Tangen Circle Motifs (object) is mixed on the reflection axis and produces the Tangen Circle Motifs (image) by reversal without altering the original shape.

Table 2. Geometric design and symmetry of motifs by Siri Nurani art work

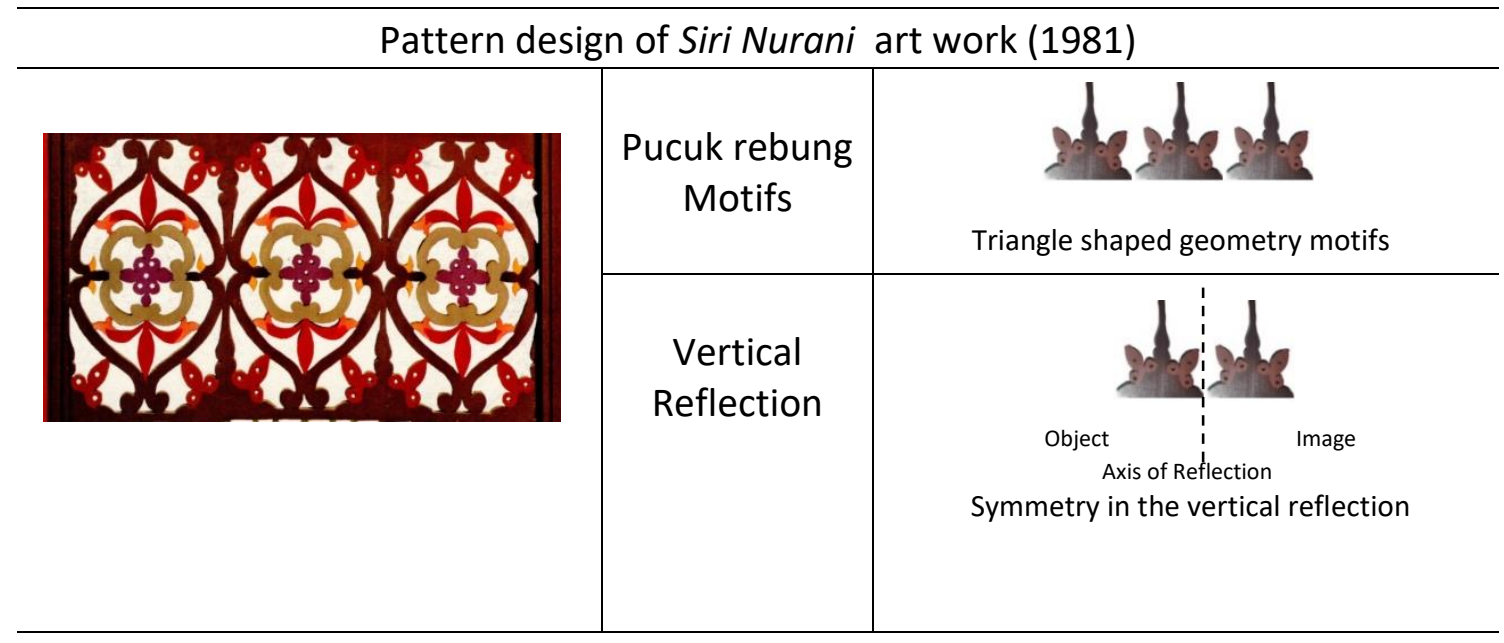

triangle shape, where the shape that displays from three sides or three angles whose two borders are the same length is known as the Pucuk Rebung., it is known as the Segi Tiga Pucuk Rebung. The pattern position of the motif shows the repetition of image vertically. Table 2 also explains the axis of reflection is located halfway between the object and the image (triangle motifs) i.e. the reflective object and the image that reverses as in the mirror. Each plane on the reflected object and image has the same distance from the reflection axis. The selection of this motif is still included in the category of simple shapes to be performed in the art work using wood carving materials. 
INTERNATIONAL JOURNAL OF ACADEMIC RESEARCH IN BUSINESS AND SOCIAL SCIENCES Vol. 10, No. 9, 2020, E-ISSN: 2222-6990 @ 2020 HRMARS

Table 3. Geometric design and symmetry of motifs by Siri Nurani art work

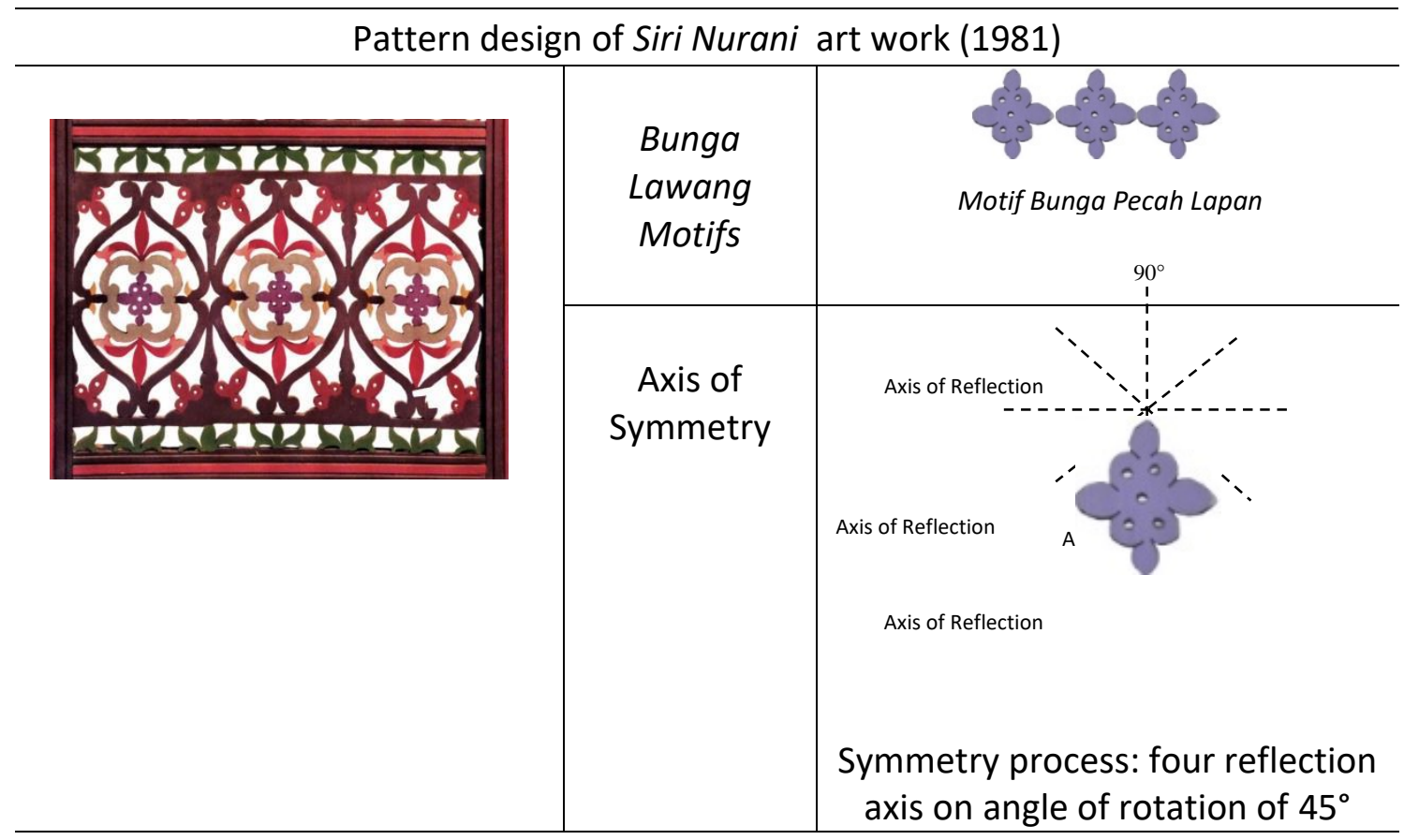

Table 3 describes eight flower motifs (Bunga Pecah Lapan motifs) to be seen in art work displaying upper view of eight petals flowers which is Bunga Lawang inspired by a hundred spices (Rashid, 2009). Bunga Pecah Lapan motifs is associated with eight-top eyelid petals as in the table. It has eight petals from the middle of dark brown-shaped shapes such as stars. These motifs can be broken down to certain parts and the pattern can be varied. While table 7 also shows the symmetry concepts of four reflections axes on the Bunga Pecah Lapan motifs. This process produces eight angle of rotation which is $45^{\circ}$ each. It is to form a pattern that has corner equilibrium through the symmetry balance arrangement. The design of the motifs in this art work is horizontally and sequentially.

Table 4. Geometric design and symmetry of motifs by Siri Nurani art work

\begin{tabular}{c|c|}
\hline \multicolumn{2}{c}{ Pattern design of Siri Nurani art work (1981) } \\
Axis of \\
Symmetry
\end{tabular}


INTERNATIONAL JOURNAL OF ACADEMIC RESEARCH IN BUSINESS AND SOCIAL SCIENCES Vol. 10, No. 9, 2020, E-ISSN: 2222-6990 @ 2020 HRMARS

Table 4 describes four flower motifs (Bunga Pecah Empat motifs) to be seen in art work displaying upper view and side view of four petals flowers. Table 4 describes four flower motifs (Bunga Pecah Empat motifs) to be seen in art work displaying upper view and side view of four petals flowers. The concept of four petals flowers is also the basic design for most designs and motifs that can be found in the most local paintings. Bunga Pecah Empat motifs are associated with four-top eyelid petals as in the table. While table 7 also shows the symmetry concepts of two reflections axes on the Bunga Pecah Empat motifs. This process produces four angle of rotation which is $90^{\circ} \mathrm{each}$. It is to form a pattern that has corner equilibrium through the symmetry balance arrangement. The design of the motifs in this art work is horizontally and sequentially.

\section{Formalistic Analysis in Symmetrical Concept}

The Principle of Balance in Symmetry

Balance of symmetry through the geometry principle gives a formal representation of the refined pattern elements arranged in the same shape, equal numbers, and sizes, textures on the left and right parts of the work. The symmetry equilibrium can be seen in the second divider, as the symmetry of the reflection (Ismail, 2014). The beauty of mathematical processing in geometric measurements as the main component of this art work, it highlights the balance in the motif arrangement which shows the continuous mapping concept.

Table 5. Symmetry balance of an axis line

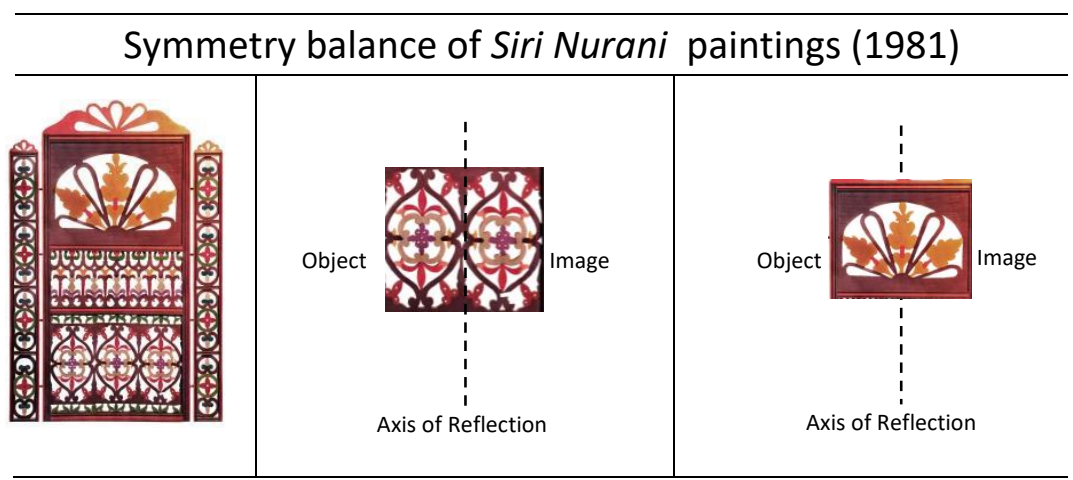

Table 5 describes the components of sculptures in the Siri Nurani paintings fulfilling the majority of space in art work. The design of the Siri Nurani paintings saw a balance of symmetric measurements on a line of the reflection axis where every carving that presented was balanced and equal to the whole composition in the work. A balance can be seen in an emphasis on the design of motifs in an art work produced in harmony through the use of artistic elements. The table above also shows the Siri Nurani paintings which are a vertical design that is designed to form a painting structure; it is produced in the symmetry measure so that it can be balance. The selection of appropriate color matches and cons to display the perspective and balance of the subject in the working space. 
INTERNATIONAL JOURNAL OF ACADEMIC RESEARCH IN BUSINESS AND SOCIAL SCIENCES Vol. 10, No. 9, 2020, E-ISSN: 2222-6990 @ 2020 HRMARS

\section{Unity Principles in Symmetry}

Table 6. Unity of repetition patterns

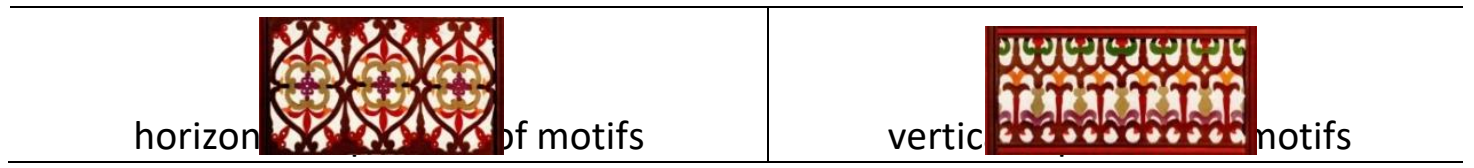

The table shows the unity in the work of the paintings resulting from the arrangement of motifs that are arranged horizontally or vertically through the repetition of a conjectured symmetry. The unity of the materials used form the composition of harmony through the recording of plane, shape, appearance and colour. The use of processed geometric motifs and flora in the art works reflects unity through Kerawang motifs. The symmetry processing of the material packaging formulated in the framework of the geometry reflects the sensitivity and the ability to produce beautiful works. Each of the patterns interconnected in the Siri Nurani paintings becomes as the starting point for the production of the composition of the work (Ismail, 2014).

\section{Analysis of Symmetry Elements in Siri Nurani Paintings}

Symmetry is a symbol of the ratio of harmony, beauty and balance found in the arrangement of patterns on the repetition of motifs. The definition of symmetry is a transformation that allows an object or pattern to remain unchanged in terms of arrangement, size and shape of the object after reflection process. Washburn and Crowe (1998) states that there are four types of methods to produce symmetrical patterns which are translation, rotation, reflection (mirroring) and lastly is a glide reflection. The diagram below explains those four methods.

Table 7. Analysis of Symmetry Elements

\begin{tabular}{|c|c|c|}
\hline Category & Descriptions & Diagram \\
\hline Translation & $\begin{array}{l}\text { Repeating motifs slides up or down either } \\
\text { vertical, horizontal or diagonal }\end{array}$ & \\
\hline Reflection & $\begin{array}{l}\text { When motif reflects and the image } \\
\text { reverses as in a mirror }\end{array}$ & \\
\hline Rotation & $\begin{array}{l}\text { When motif turns around a point. Rotation } \\
\text { can be } \\
60 \text { 을 } 90 \text { 으, } 120 \text { o or } 180 \text { ․ }\end{array}$ & \\
\hline $\begin{array}{l}\text { Glider } \\
\text { Reflection }\end{array}$ & $\begin{array}{l}\text { When motif translates along the axis and } \\
\text { at the same time reflects across an axis }\end{array}$ & \\
\hline
\end{tabular}

A.Gallian (1998) stated that the formation of repetitive pattern dimensions in one linear direction (frieze) is one of the processes in the group of symmetry. The 'frieze' pattern is classified into a group of strip planes and it is a mathematical concept for classifying patterns on two-dimensional surfaces. Radaelli (2011) stated that frieze is seen as a boundary pattern found in human culture to produce decoration on all works of art. It depends on the nature of the object; these decorative motifs can be linear, round circles (as on the neck of the vase) or follow the shape of a polygon (diagram with more than four angles). The pattern of the decoration is open and not closed in a linear and infinite line. 
INTERNATIONAL JOURNAL OF ACADEMIC RESEARCH IN BUSINESS AND SOCIAL SCIENCES Vol. 10, No. 9, 2020, E-ISSN: 2222-6990 @ 2020 HRMARS

The frieze pattern exhibits a fixed translation in one direction only. Based on this group of isometric planes there are 7 basic frieze patterns that apply the concept of transformation using these four types of repetition techniques in a mathematical context. The system for classifying this group of symmetry is to use a number and key code scheme to classify this 'frieze' pattern. There are two classifications of frieze, namely four symbol-notation $(p, x, y, z)$ and two symbol-notation $(x, y)$. These symbols provides a brief and easy-to-understand guide to the symmetry operations used in each of the seven classes

Table 8. Analysis of Symmetry Elements

\begin{tabular}{ccc}
\hline No. & Symmetr & Explaination
\end{tabular}

Table 8 shows the analysis obtained from Siri Nurani Paintings (1996) by using symmetry elements through the transformation process. It forms a symmetry group to analyze pattern designs that are classified through seven frieze patterns. 
INTERNATIONAL JOURNAL OF ACADEMIC RESEARCH IN BUSINESS AND SOCIAL SCIENCES Vol. 10, No. 9, 2020, E-ISSN: 2222-6990 @ 2020 HRMARS

Table 9. Analyse model friezes table

\begin{tabular}{|c|c|c|c|}
\hline \multicolumn{4}{|c|}{ ANALYSE MODEL FRIEZES TABLE } \\
\hline Paintings & $\begin{array}{c}\text { Types of Frieze } \\
\text { Pattern }\end{array}$ & Pattern Design & Analyses \\
\hline \multirow{6}{*}{ 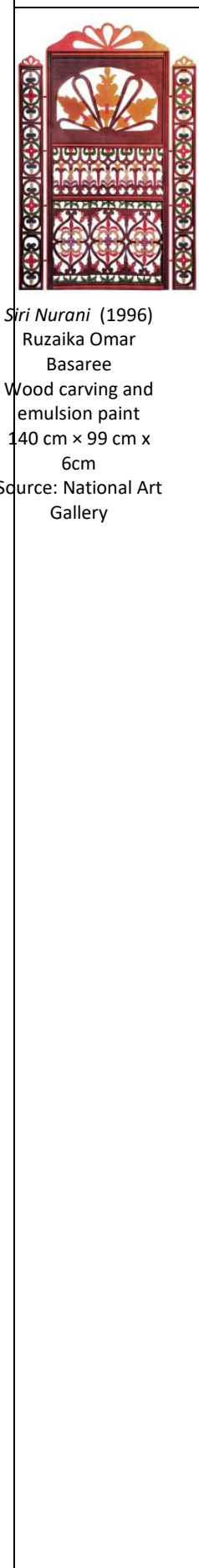 } & $\begin{array}{c}\text { Translation } \\
\text { ( p111/1) }\end{array}$ & (2) & 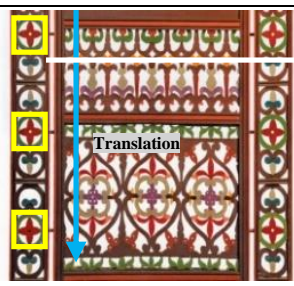 \\
\hline & $\begin{array}{c}\text { Translation and } \\
\text { vertical } \\
\text { reflection } \\
(\mathrm{pm} 11 / \mathrm{m})\end{array}$ & & 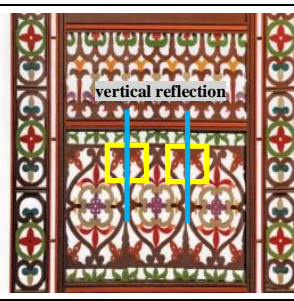 \\
\hline & $\begin{array}{c}\text { Translation and } \\
\text { horizontal } \\
\text { reflection } \\
\text { (p1m1/1m) }\end{array}$ & & 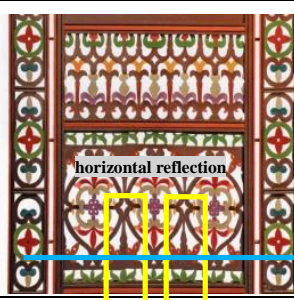 \\
\hline & $\begin{array}{c}\text { Translation and } \\
180^{\circ} \text { rotation } \\
(\mathrm{p} 112 / 12)\end{array}$ & & 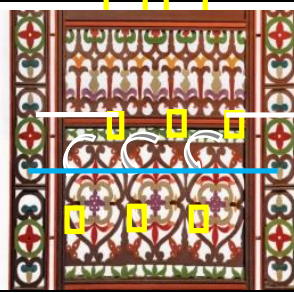 \\
\hline & $\begin{array}{c}\text { Translation and } \\
\text { glide reflection } \\
\text { (p1a1/1g) }\end{array}$ & & 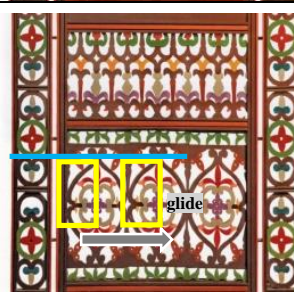 \\
\hline & $\begin{array}{c}\text { Translation, } \\
\text { glide reflection, } \\
\text { vertical } \\
\text { reflection, } \\
\text { horizontal } \\
\text { reflection and } \\
\text { rotation } \\
\text { (pma2/mg) }\end{array}$ & $\beta$ i & 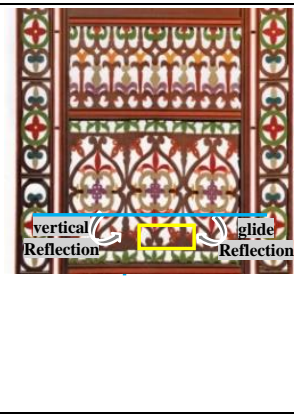 \\
\hline
\end{tabular}


INTERNATIONAL JOURNAL OF ACADEMIC RESEARCH IN BUSINESS AND SOCIAL SCIENCES Vol. 10, No. 9, 2020, E-ISSN: 2222-6990 @ 2020 HRMARS

\begin{tabular}{|c|c|c|c|c|}
\hline $\begin{array}{c}\text { Translation, } \\
\text { glide reflection, } \\
\text { vertical } \\
\text { reflection, } \\
\text { horizontal } \\
\text { reflection and } \\
\text { rotation } \\
\text { (pma2/mg) }\end{array}$ & &
\end{tabular}

\section{Art Appreciation in the Context of Ethnomatematics}

The meaning of appreciation of art in the ethnomathematic context in the Siri Nurani paintings is connected through several related concepts namely:

\section{Calculation System}

Ismail (2012) stated that the Malay art culture and number concept occurred in the production of the Siri Nurani paintings by using the rules and calculation systems as artistic expression. Pattern design movement was generated through relationships with the concept of a number calculation due to system count in the production of art paintings. These arrangements are defined as the subject that moves recurrence in the order of pattern. The Siri Nurani art work shows a consistent movement of the rhythm because it has similar motifs form, same size, same distance, shape and space. The repetition of motifs uses the symmetry concept of a continuous mapping, producing interesting patterns. Most of the art works adhere to the general principles of mathematical concepts using the symmetric concepts that assert balance and unions.

Table 10. Calculation system in axis of rotation

\begin{tabular}{c}
\hline \multicolumn{3}{c}{ Rotation axis of art motifs } \\
\hline
\end{tabular}

Table 10 describes the recurrence process of an image that occurs in the artistic sculpture of Siri Nurani paintings on the object (motif), which is rotational transformation. The $180^{\circ}$ rotation angle needs to be done several times to bring the plane back to where it starts. Rotating all the dots for an object at a fixed point known as the center, through a particular rotation and direction. The original 
INTERNATIONAL JOURNAL OF ACADEMIC RESEARCH IN BUSINESS AND SOCIAL SCIENCES Vol. 10, No. 9, 2020, E-ISSN: 2222-6990 @ 2020 HRMARS

object with the image has the same shape and size, but the image formed shows the different directions.

\section{Arts (Carpentry)}

Ismail et al. (2012) described ethnomatematics as connecting the arts involving carpentry through carving arts. The use of various measurement and calculations system in Malay craftsmanship to produce harmonious geometrical shapes applied. It has been suggested that the mathematical elements have long been practiced through carpentry art. Siri Nurani artworks applying the kerawang-shaped concept that uses woodwork instead of canvas.. The mastery of craftsmanship by the early societies resulted from the idea of exploiting the material from the environment and being used as a production of art work. Skilled craftsmanship and creativity make their art works produced good 2D artworks.

Table 11. Art in woodcarvings

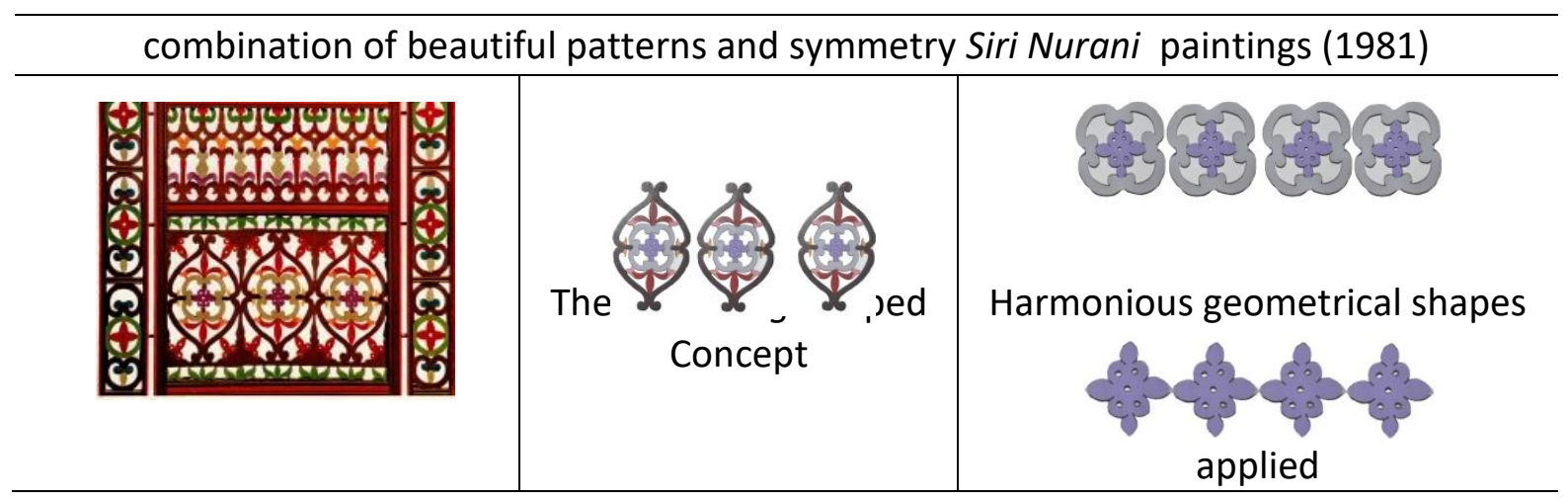

Table 11 show the Wood is used to shape the building structure and carving motifs, it requires a lot of mathematical operation skills to produce a combination of beautiful patterns and symmetry. The composition and originality of traditional carving artwork that applied geometrical motifs design is recognized by the fineness and unique arrangement pattern.

\section{Conclusion}

This study confirms that Ethnomatematics concept is one strength in traditional Malay elements and have been adapted in the artworks of painting. The results of mathematical research through art appreciation in the artworks devoted to the search for meaning of Ethnomathematics towards the selected artworks of traditional Malay selected which is Siri Nurani . Basically a painting artwork is evaluated from the point of view of aesthetic beauty and content of its meaning. From the findings of the research outlined through the paintings studied, it is clear that there is a structure of the principle of symmetry in each processing based on mathematical calculations. The entire content of the artwork contains aesthetics that create the value of beauty. It is hoped that this research can contributes new information and can encourage the community to appreciate the beauty of works of art from different perspectives in terms of the beauty of mathematical concepts, practices and values. It is seen in the motifs and patterns embodied in the paintings as well as the literal and implicit mathematical abilities of the art itself. 
INTERNATIONAL JOURNAL OF ACADEMIC RESEARCH IN BUSINESS AND SOCIAL SCIENCES

Vol. 10, No. 9, 2020, E-ISSN: 2222-6990 (C) 2020 HRMARS

\section{References}

Alicia, S., \& Jessica, M. (2006). Friezes Pattern. Minnesota State University Moorhead.P.3-5. Ahmad, J., \& Idris, S. R.(1996). Ukiran Melayu. Petaling Jaya: Penerbit Pinang.

Anuwar, T. (2013).Falsafah Etnomatematik. Makalah Dibentangkan Di Seminar Ethnosains Akademi Sains Islam Malaysia (ASASI) Ke-2.Pusat Dialog Peradaban. Petaling Jaya: Universiti Malaya.P.1-4.

Basaree, R. O. (2016).Simbiosis: Keharmonian Seni Tradisional Dan Seni Digital Kontemporari. Balai Seni Visual Negara. Kuala Lumpur

Basaree, R. O. (2008). The Frieze Pattern in Malay Wood Carving. Jurnal Perintis Pendidikan. Shah Alam: Universiti Teknologi, 43-47.

Ismail, A. R. (2014).Kesenian Dan Fabrik Melayu: Alam Sebagai Motif Kraf Tangan Fabrik Melayu Tradisi. Shah Alam: Penerbit Universiti Teknologi Mara.

Ismail, M. R., Tarmizi, R., Ayub, F.,Yusof, N., \& Kartini, S. (2012). Seni Warisan Melayu: Suatu Manifestasi Etnomatematik. Rampaian Etnomatematik. Universiti Putra Malaysia: Institut Penyelidikan Matematik.

Ismail, M. R. (2004).Etnomatematik. Matematik Merentas Tamadun. Falsafah Pengajian Sejarah Matematik. Kuala Lumpur: Dewan Bahasa Dan Pustaka.

Ismail, M. R., \& Atan, K. A. (2010). Mathematics in the Malay world prior to the Arrival of Western Mathematics. International Conference on Mathematics Education Research (ICMER). P.729734.

Jusoh, A., Sauman, Y., \& Ramli, Z. (2011). Gendang Gangsa di Asia Tenggara: Tinjauan terhadap Motif Berunsur Geometri. SARI: Jurnal Alam dan Tamadun Melayu, 29 (2). pp. 21-44. ISSN 0127-2721.

Rashid, M. S. (2009).Cadangan Kaedah Kod 'S' Bagi Penamaan Dan Penentuan Motif Bunga Ukiran Melayu Dalam Proses Inventori. Kertas Kerja Ini Telah Dibentangkan DiPersidangan Antarabangsa Kesenian 2009 - Seni Dekorasi : Pelestarian \& Pembangunan, Anjuran Akademi Pengajian Melayu Universiti Malaya, Hotel Singgahsana, Petaling Jaya.P.1-13.

Sheppard, M. (1980). Mekarnya Seni Pertukangan Malaysia. Eastern Universiti Press Sdn. Bhd. Kuala Lumpur. Patterns.European Science publishing Ltd.

Shinley, L. (2001).Ethno Mathematics As A Fundamental On Instructional Methodology. University Towson USA:Mathematics Department Towson.

Salleh, A. R. (2009). Matematik Dalam Budaya Melayu. Bangi: Penerbit Universiti Kebangsaan Malaysia. 